\title{
The Small Pelagic Fisheries of Sarangani Bay, Southern Mindanao, Philippines
}

\author{
Laila L. Emperua ${ }^{1, \star}$, Emelyn A. Donia ${ }^{1}$, Miyong J. Biaca ${ }^{1}$, Rosemarie R. Pechon ${ }^{1}$, Al-Azeez T. Pautong ${ }^{1}$, Therese \\ Angeline D. Balonos ${ }^{1}$ \\ ${ }^{1}$ Bureau of Fisheries and Aquatic Resources XII, \\ BFAR XII Government Center, Carpenter Hill, Koronadal City
}

\section{A B S T R A C T}

Historically, the waters of Sarangani Bay have rich fishing grounds. Fisherfolks depend mostly on fishing and have been the primary source of living. The study covered two municipal landing sites in Sarangani Province and one site in General Santos City, with its fishing ground in Sarangani Bay, to have information on the status of pelagic resources.

Results show a decreasing trend in catches of pelagic species from $92 \%$ in 2008 to $86 \%$ in 2012 . The same decreasing trend can be seen in the number of species recorded compared to the previous study, from 401 species to 249. With regards to fishing gears used in the bay, there are five commonly used: multiple hook and line, scoop net, surface gill net, encircling gill net, and troll line.

Analysis of data was made using different analytical models contained in FiSAT II software. Growth parameters like maximum length (Lmax), K-values, total mortality (Z), natural mortality (M), fishing mortality (F), and exploitation ratio were computed using the length data.

Recruitment pattern analysis, virtual population analysis, and yield per recruit were also analyzed.

^E-mail: lailaemperua@gmail.com

Keywords: small pelagic, Sarangani bay

Received: 9 February 2017

Accepted: 10 July 2017

\section{IN TRODUCT I ON}

น he small pelagic are a diverse group of marine fishes inhabiting the upper surface layer of the water column (waters not exceeding a depth of 200 $\mathrm{m})$, usually above the continental shelf. They consist of mackerel and herring-like species but also include flying fishes, halfbeaks, and fusiliers.

Small pelagic are mostly schooling, planktivorous feeders. Yesaki (1983) classified the pelagic fishes into three groups based on their feeding habits, namely planktivores, primary carnivores, and secondary carnivores (cited in Trinidad et al. 1993). The small pelagic falls into the first two categories. Anchovies and mackerels are considered phytoplanktivores while the clupeids and scads are primary carnivores. While the diet of anchovies and mackerels contains phytoplankton, crustaceans (especially copepods) are its main diet source (Dalzell and Ganaden 1987). Small pelagic fishes usually attain a maximum weight of less than $500 \mathrm{~g}$ and are characterized by short life spans, fast growth rates, and subsequent high natural mortalities (Dalzell and Corpuz 1990b).

According to Zaragoza et al (2004), small pelagic fishes as a group consist predominantly of round scads
(Decapterus spp., Carangidae), anchovies (Stolephorus spp., Engraulidae), sardines (Sardinella spp., Clupeidae), and mackerels (Rastrelliger spp., Scombridae). Also included in this group are the round herrings (Clupeidae), fusiliers (Caesionidae), bigeye scads (Carangidae), flying fishes (Exocoetidae), and halfbeaks (Hemiramphidae).

Sarangani Bay is located in Southern Mindanao between 5033'25'-606'15'N and 124022'45'-125019'45”E.

There were two definitions of Sarangani Bay. Technically, it is the primary enclosed marine cove bounded by the coastal lands of General Santos City and the municipalities of Alabel, Glan, Malapatan, and Maasim of Sarangani Province with the mouth defined by an imaginary line connecting Tampuan Point in Maasim to Sumbang Point in Glan. Jurisdictionally, the bay has a larger mouth with an imaginary line perpendicular to the coast connecting Pinol Point in Maitum and Tinaca Point in Glan. This defines the greater Sarangani Bay, which is the Protected Seascape of Sarangani Province of Southern Mindanao.

This paper presents the results of the study with emphasis on pelagic fisheries that have economic importance not only to the fisherfolk of Sarangani Province and General Santos City but also to the region in general. 


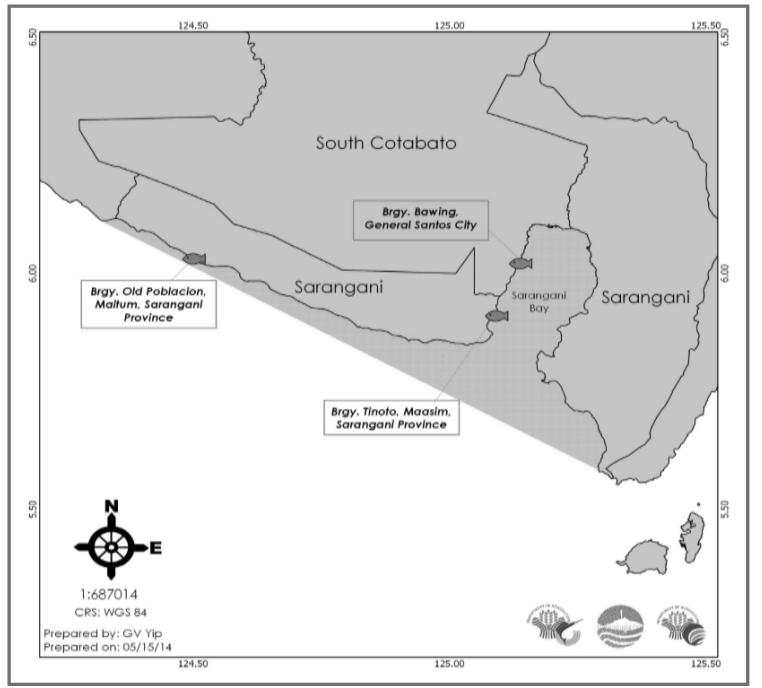

Figure 1. Map of Sarangani Bay showing the sampling sites.

\section{ME T H O D O L O G Y}

\section{Sampling Sites}

Fish catches from municipal fisheries were collected in three selected fish landing centers in SARGEN area of Region XII. These landing sites were Bawing in General Santos City, Tinoto of Maasim, and Old Poblacion of Maitum as the fishing ground (Figure $1)$.

\section{Data Gathering}

The sampling scheme designed by the National Fisheries Research and Development Center (NFRDI) was followed in the region. Monthly surveys were undertaken in the three landing centers covering only municipal fisheries. However, since the study site is mainly municipal water, gathering of fish catch data began on the first and second day of the month with two landing sites monitored and every three days thereafter. Sampling days per month varied from 20-21 days; it would have 21 survey days during the month, which have 31 calendar days.

\section{Data Collected}

\section{a. Boat and Gear Inventory}

An inventory of fishing boats/bancas and gears used was undertaken in landing centers monitored only. All existing fishing gears that were gathered were identified based on the catalog of fishing gears. Other data on fishing boats and gears were secured from the municipal/city profile through the help of fishery technicians.

\section{b. Fish catch data}

Fish caught from fishing bancas/boats that unloaded at fish landing centers were monitored. Data on the following were recorded: total fish catch, fishing gear used, duration and time of fishing, fishing ground, catch composition, and length-weight measurement. Sub-samples of fish caught from the sampled boats were collected when the total number of boats and volume of fish unloaded was too large to be completely measured due to time constraint. Fishing boats landed, which could not be covered by sampling due to physical distance, were recorded as part of total boats that landed during the survey day.

\section{Data encoding, quality control, processing and analysis}

All data were submitted to the NSAP of BFAR 12, Koronadal City for processing and encoding. Data collected from monitored sites were encoded in Microsoft Excel 2007 using a designed matrix or template. Two templates were designed for data entry; one for catch and effort, and the other one for length frequency of species analyzed for further processing. The template used for catch and effort and fishing boat effort enabled the data analysts to do error tracking, editing, data reconciliation, sorting, and filtering which were all done in MS Excel using the pivot table routine. By pivoting, the analysts could easily generate tables and graphs needed for the results and discussions. While the other template used for length frequency and data generated could be easily transferred to FiSAT software for analysis of growth parameters and other necessary data.

\section{a. Catch per unit effort (CPUE) and production estimates}

Monthly catch per unit effort per gear was computed and standardized as kilograms per day (kg/ day). Fishing hours effort were converted into days and these data were coming from the municipal sector only. The calculated annual CPUE (kg/day) were obtained by dividing the monthly fish production with the total number of boats landed or monitored considering that the boat goes fishing only once a day.

Annual production estimates were simply the product of catch per unit effort (CPUE), average fishing days, and total boat count in the landing centers.

\section{b. Catch composition and dominant species in the catch}

From the data processed in the spreadsheet (MS Excel) through the pivot table routine, the dominant species were determined based on the fish's contribution in terms of weight to the total harvest from 2008-2012. The species were arranged by percentage ranking in descending order. 
Table 1. Annual number of municipal fishing gears monitored

in the landing centers, 2008-2012.

\begin{tabular}{ccccccc}
\hline Gear Type & $\mathbf{2 0 0 8}$ & $\mathbf{2 0 0 9}$ & $\mathbf{2 0 1 0}$ & $\mathbf{2 0 1 1}$ & $\mathbf{2 0 1 2}$ & Total \\
\hline MHL & 138 & 180 & 187 & 137 & 119 & 761 \\
HL & 6 & 15 & 35 & 36 & 33 & 125 \\
EGN & 12 & 21 & 31 & 32 & 18 & 114 \\
SGN & 14 & 14 & 3 & 20 & 33 & 84 \\
BSLL & 33 & 5 & 2 & 6 & 31 & 77 \\
TL & 10 & 7 & 9 & 9 & 10 & 45 \\
BSGN & 5 & 1 & 3 & 6 & 11 & 26 \\
SN & 7 & 1 & 1 & 2 & 9 & 20 \\
DGN & 2 & 2 & & & & 4 \\
CN & 3 & & & & & 3 \\
FC & & 1 & & & & 1 \\
FH & & 1 & & $\mathbf{2 4 8}$ & $\mathbf{2 6 4}$ & $\mathbf{1 2 6 1}$ \\
\hline Total & $\mathbf{2 3 0}$ & $\mathbf{2 4 8}$ & $\mathbf{2 7 1}$ & & &
\end{tabular}

Table 2. Number of municipal fishing boats, by municipality and fisherfolk in Sarangani Bay (2010 and 2013).

\begin{tabular}{ccccccc}
\hline \multirow{2}{*}{ Municipality } & \multirow{2}{*}{ Motorized } & \multirow{2}{*}{ Non-motorized } & \multirow{2}{*}{ Total } & \multicolumn{3}{c}{ No. of Fisherfolk } \\
\cline { 5 - 7 } & & & & Full-time & Part-time & Total \\
\hline Glan & 830 & 125 & 1,645 & 2,290 & 838 & 3,128 \\
Maasim & 530 & 207 & 1,208 & 1,809 & 560 & 4,073 \\
Maitum & 1001 & 475 & 835 & 680 & 298 & 978 \\
Kiamba & 360 & $92^{*}$ & 167 & 849 & 62 & 911 \\
Alabel & $75^{*}$ & $278^{*}$ & 663 & $\star 2486$ & $\star 1820$ & $\star 4,306$ \\
Malapatan & $385^{*}$ & $220^{*}$ & 456 & - & - & - \\
General Santos City & $236^{*}$ & & & & &
\end{tabular}

\section{c. Relative abundance/seasonality of five major species}

In MS Excel, pivot table routine was used to determine the taxonomic identification count from family to species. The data used in processing was the combined data of catches and gears per year. But in the determination of seasonality of the five major species, only monthly catches of the species were used.

\section{Estimation of population parameters}

Population parameters were estimated using the FAO-ICLARM Stock Assessment Tools (FiSAT) (Gayanilo et. al. 1997). This tool was used to analyze the length frequency data of Mene maculata, Selar crumenophthalmus, and Rastrelliger kanagurta caught by different gears to determine the exploitation values.

The formula used in computing the exploitation rate $(\mathrm{E})$ is: $\mathrm{E}=\mathrm{F} / \mathrm{M}+\mathrm{N}$ or $\mathrm{E}=\mathrm{F} / \mathrm{Z}$. The standard $\mathrm{E}$ value is 0.5 . If the value obtained is less than 0.5 , the resource is unexploited. However, if the value exceeded from its $\mathrm{E}_{\text {opt }}$ of 0.5 that means the resources/stocks are already overfished. Other data such as Lmax, $\mathrm{L}_{\infty}$, phi prime, mortality and recruitment pattern, probabilities of capture, VPA, and relative yield per recruit were also processed in FiSAT using the length frequencies data.

\section{RES ULT S}

\section{Fishing boats and gears}

The annual inventory of municipal fishing gears catching small pelagic species in the landing centers for 2008-2012 monitored was shown in Table 1. There were 12 fishing gears used in the three sites with an average of 504 for the past five years catching small pelagic. The three sampling sites have different important gears. For Bawing, General Santos City it is multiple hook and line; surface gillnet for Old Poblacion, Maitum; and multiple hook and line as well for Tinoto, Maasim.

The highest number of gears was recorded for 2010 with 271 different gears. Multiple hook and line, single hook and line, encircling gill net, surface gill net, and bottom set long line are the major gears used to catch pelagic fishes.

The number of fishing boats and the number of fisherfolk found in Sarangani Bay for 2013, except for Alabel, Malapatan, and General Santos where the only available data was in 2010, were listed in Table 2. The municipality with the highest number of municipal boats and with 3,128 fisherfolk, both full-time and part-time, is Glan. Alabel, on the other hand, has 167 operating boats 
Table 3. Comparison of annual fish harvest estimates (MT) and relative percentage contribution of small pelagic to the total fish harvest in Sarangani Bay, 2008-2012.

\begin{tabular}{cccc}
\hline Year & Est. Harvest & Pelagic Catch & $\%$ \\
\hline 2008 & 2,210 & 2,039 & 92 \\
2009 & 2,335 & 2,026 & 87 \\
2010 & 1,720 & 1,564 & 91 \\
2011 & 2,285 & 1,988 & 87 \\
2012 & 3,248 & 2,811 & 86 \\
\hline Total & 11,798 & 10,428 & \\
\hline
\end{tabular}

and 911 fisherfolk. Alabel has the lowest number of bancas because this municipality is used more as a docking area of commercial vessels operating in the Moro Gulf. Among the six coastal municipalities, Maitum recorded 1,001 motorized boats with 2,369 fisherfolk. Boats coming from this area mainly catches flyingfishes using surface gill net. Drying and other types of processing for this species is the livelihood for the women's group and associations in the locality. Glan, on the other hand, has the highest number of non-motorized boats. Notable fishing areas are the waters of Siguel, Glan, Lun and Maasim (Aprieto 1992). Aprieto (1992) also cited that the estimated number of non-motorized banca operators were 1,959 and were concentrated in nearshore waters and may be considered as bona fide small-scale fishermen of Sarangani Bay while this study recorded 1,622 municipal boats with different gears modified for catch efficiency. Daily fishing operations last from 5-12 hours (Aprieto 1992) and today ranges from 3-13 hours.

\section{Catches and Catch per unit effort (CPUE)}

Comparison of annual catches of small pelagic species, demersal and invertebrates caught in Sarangani Bay, 2008-2012 (Figure 2), pelagic species showed a decreasing trend from the year 2008-2011 except for 2012 wherein highest estimated harvest is observed at about $2,811 \mathrm{MT}$ and contributed $88.4 \%$ to the total harvest. Demersal species exhibited a decreasing trend but recorded the highest production in 2012 (139 MT) with $4.9 \%$ contribution. The increase in 2012 harvest is due to the increase in the number of enumerators doing the sampling. Comparing the catches of demersal and invertebrates, the latter has the highest production and

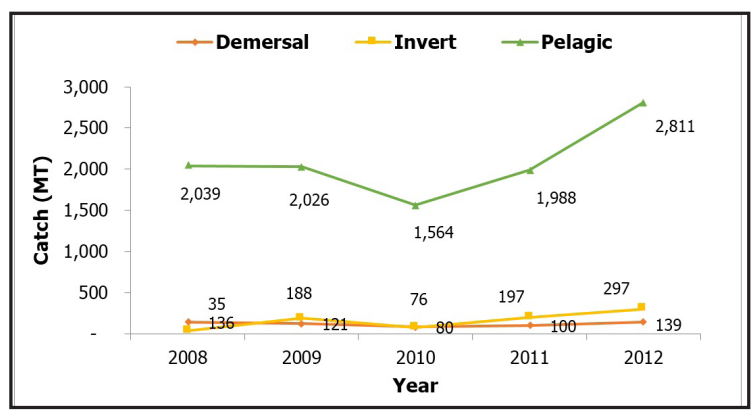

Figure 2. Comparison of annual catches of small pelagic species, demersal, and invertebrates caught in Sarangani Bay, 2008-2012. comprised mainly of squids with some blue crabs.

Table 3 shows the annual fish harvest estimates (MT) and relative percentage contribution of the small pelagic to the total fish harvest in three landing sites of Sarangani Bay for 2008-2012. As the table suggests, there is a decrease in percentage contribution of small pelagic catch from $92 \%$ in 2008 to $86 \%$ in 2012 . The highest contribution was observed in 2008 with $92 \%$ and Mene maculata or locally called "bilong-bilong" with 13,200 kg. (2012) landed catch dominating the bulk of production and lowest contribution observed in 2009 with 87\%. Aprieto in 1992, tabulated the major fish groups landed by municipal fisheries in 1989 and moonfish is also included in the major species landed. The results clearly showed that a small pelagic stock has a great contribution to the total production of Sarangani Bay.

Figure 3 shows the annual catch per unit effort (kg/day) trend of major fishing gears catching small pelagic in Sarangani Bay from 2008-2012. Scoop net locally called "sigpaw" has an average CPUE of $35 \mathrm{~kg} /$ day and peaked in 2010 with the highest CPUE of $92.5 \mathrm{~kg} / \mathrm{day}$. Surface gillnet (pukot) is observed to have a fluctuating trend in CPUE from 2008-2012 with an average CPUE of $27.2 \mathrm{~kg} /$ day. Troll line (subid) and bottom set long line (palangre), except for multiple hook and line (undak), exhibited the same CPUE and only in 2010 did it record a CPUE of $6.1 \mathrm{~kg} /$ day.

\section{Relative Abundance}

The relative distribution of the top ten small pelagic fish family to the pelagic fish harvest of Sarangani Bay is shown in Figure 4. There were twelve families monitored and sampled from 2008-2012, namely

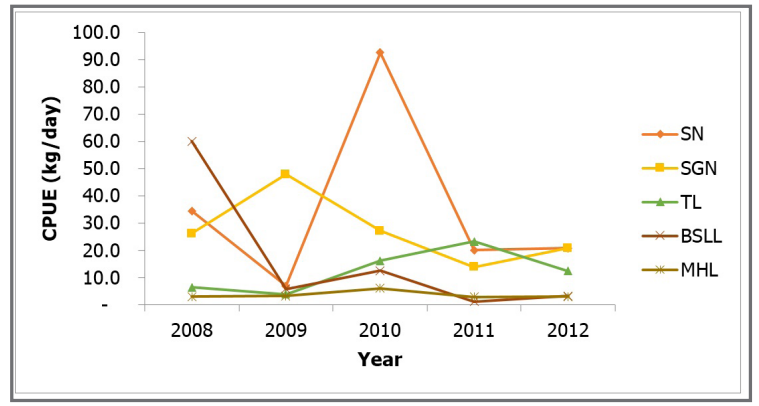

Figure 3. Comparison of annual catch per unit effort (kg/day) of major fishing gears catching pelagic species in Sarangani Bay, 2008-2012. 


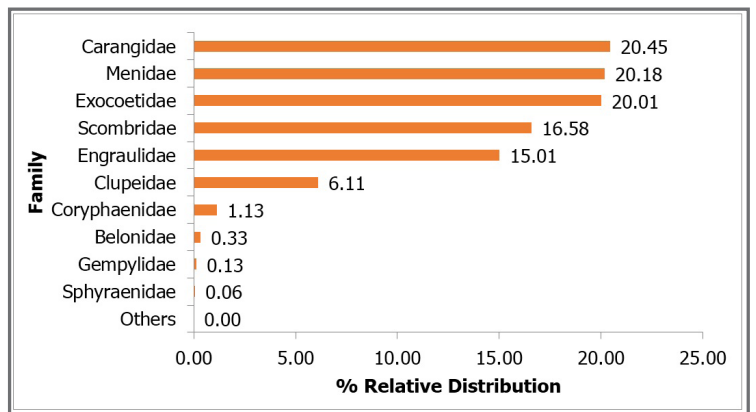

Figure 4. Relative distribution of top ten small pelagic fish family to estimated small pelagic fish harvest of Sarangani Bay.

Carangidae (scads), Menidae (moonfish), Exocoetidae (flyingfish), Scombridae (tuna and mackerels), Engraulidae (anchovies), Clupeidae (sardines), Coryphaenidae (dorado), Belonidae (balo), Gempylidae (snake mackerel), Sphyraenidae (barracuda), and Trichiuridae (cutlassfishes). Megalopidae (tarpon) with the Carangidae, recorded $20.5 \%$, the highest percentage contribution to the total catch while Megalopidae recorded the lowest with $0.01 \%$.

In terms of relative abundance of fish genera to estimated small pelagic fish harvest, it was observed that Mene had the highest percentage contribution of $20.2 \%$, followed by Encrasicholina 14.9, Cypselurus 13.2\%, Selar 9.4\%, Decapterus 9\%, Sardinella 5.8\%, Katsuwonus 5.4\%, Thunnus 3.8\%, and the lowest with 3.6\% Cheilopogon

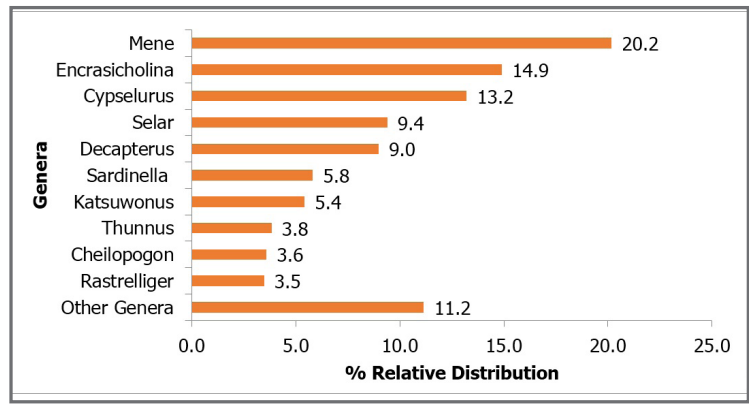

Figure 5. Relative distribution of major small pelagic fish genera to estimated small pelagic fish harvest of Sarangani Bay.

and other genera accounted for $14.7 \%$ (Figure 5).

Mene maculata locally called by the Generals and Sarangan "bilong-bilong" and commonly caught by multiple hook and line dominated the catch in terms of weight with $20.2 \%$ followed by Encrasicholina punctifer (bolinao) 14.9\%, Selar crumenophthalmus (tulay or matambaka) at $8.6 \%$, Cypselurus spp. (bolador or bangsi) $6.1 \%$, Katsuwonus pelamis (sambagon) at $5.4 \%$, Cypselurus opisthopus (bangsi) 5.2\%, Decapterus kurroides 4.8\%, Sardinella lemuru 4\%, Thunnus albacares 3.6\%, and other species with $27.3 \%$ (Figure 6).

Among the gears shown in Figure 7, 14 gears were recorded and multiple hook and line exhibited the highest percentage contribution to the pelagic fish harvest with $51.8 \%$, scoop net at $18.1 \%$, surface gill net that catches mainly flyingfishes at $17.5 \%$, encircling gill net

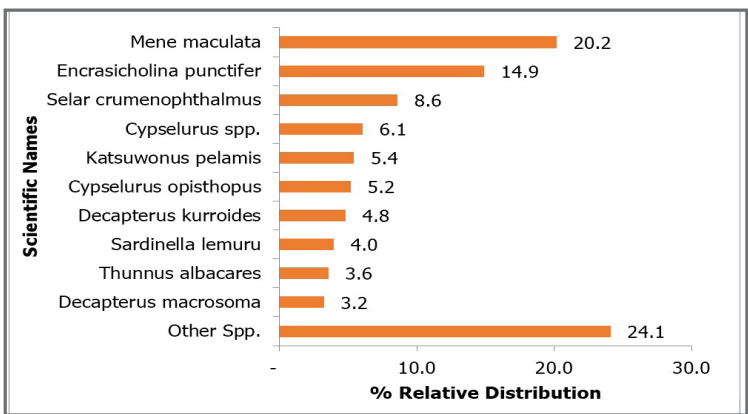

Figure 6. Percent relative distribution of top ten major small pelagic to estimated fish harvest of Sarangani Bay, 2008-2012.

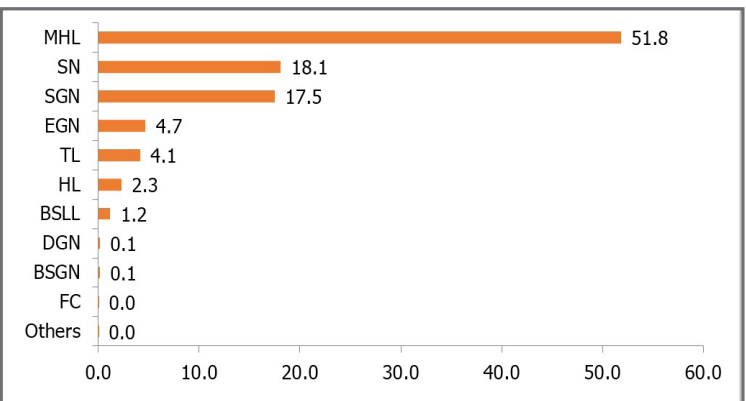

Figure 7. Percent relative distribution of fishing gears identified operating in Sarangani Bay for 2008-2012.

at $4.7 \%$, troll line at $4.1 \%$, hook and line at $2.3 \%$, bottom set longline at $1.2 \%$, and drift gillnet, bottom set gillnet, fish corral and other gears accounted for almost $1.5 \%$. In addition, results of the studies of MSU-SUML (1997) and the results of the PCRA activities, the most common fishing method is hook and line/handline/dropline.

\section{Seasonality}

There were only five major species analyzed for its seasonality. Selection of species is based on its dominance. The monthly seasonal pattern observed for Mene maculata, Selar crumenophthalmus, and Sardinella lemuru from the year 2008-2012 is shown in Figure 8. Variations in seasonal pattern were observed for $M$. maculata, with peak in month of November in 2008, February in 2009, December in 2010, October in 2011 and November in 2012. It was in 2012, the highest peak was noticed and the lowest was observed in several months (Figure 8a).

In the case of Selar crumenophthalmus, it was in 2010 that the highest seasonal catch was observed. In 2009, the seasonal pattern peaked in December, January in 2011, and July in 2012 (Figure 8b). Sardinella lemuru shows also a variation in monthly seasonal pattern with peaks in August in 2008, January in 2009, January in 2010, September in 2011 and March in 2012. Highest peak was observed in January of 2009 (Figure 8c).

Scombrid group has also variations in seasonal pattern. For Katsuwonus pelamis, highest peak is observed during the month of February 2011. For 2008 highest seasonal is in July, December in 2009 and 2010, 


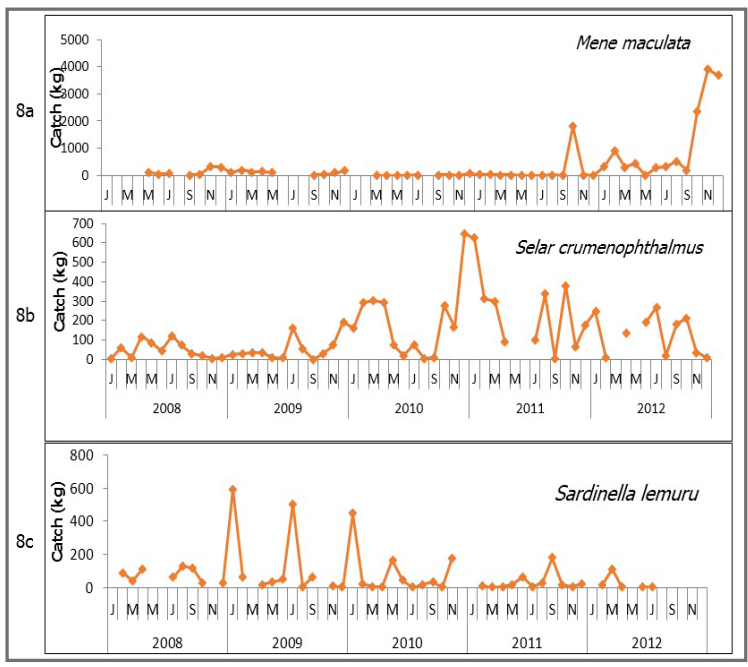

Figure 8. Monthly seasonality observed for M. maculata, S. crumenophthalmus, and S. lemuru caught in Sarangani Bay for the year 2008-2012.

and April in 2012, while for Thunnus alabacares peaks in August in 2008, June for 2009 and 2012, December in 2010, and October in 2011 (Figure 9).

There were four major species selected to determine its length at first maturity using the five-year data sets of length frequency. Length at first maturity for M. maculata is $14 \mathrm{~cm}$ and $53 \%$ of the species are caught before they reach its maturity stage using the multiple hook and line (Figure 10). Higher percentage catches of immature sizes of S. crumenophthamus with length at first

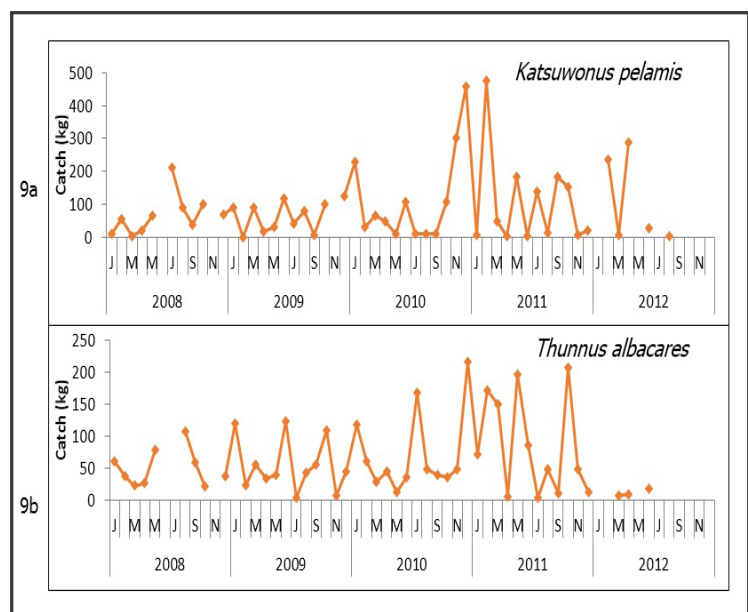

Figure 9. Monthly seasonality observed for the Scombridae group, Katsuwonus pelamis and Thunnus albacares caught in Sarangani Bay for the year 2008-2012.

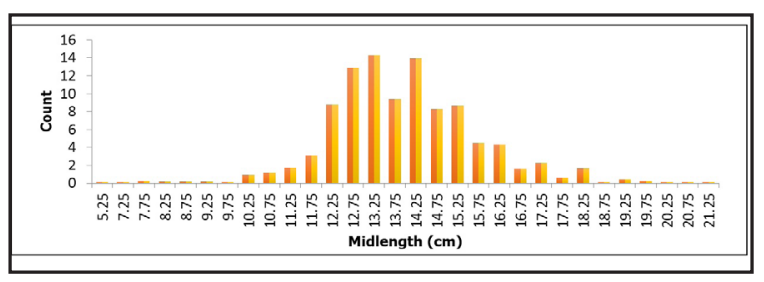

Figure 10. Length frequency distribution showing the length at first maturity of Mene maculata caught in Sarangani Bay, 2008-2012. maturity of 21.5 are caught by surface gill net with $100 \%$ of the species are immature followed by encircling gill net (78\%), and $58 \%$ for multiple hook and line (Figure 11). Comparing length sizes to its length at first maturity of 23 $\mathrm{cm}, R$. kanagurta caught by different types of gears and the troll line catches $100 \%$ juvenile sizes, E77\%, encircling gill net, multiple hook and line $68 \%$, and surface gill net $67 \%$ (Figure 12). Compared to its length at first maturity of 17.6, immature sizes also of D. macrosoma ranges from $48 \%$ to $50 \%$ are observed and these are caught by multiple hook and line and bottom set longline, respectively (Figure 13).

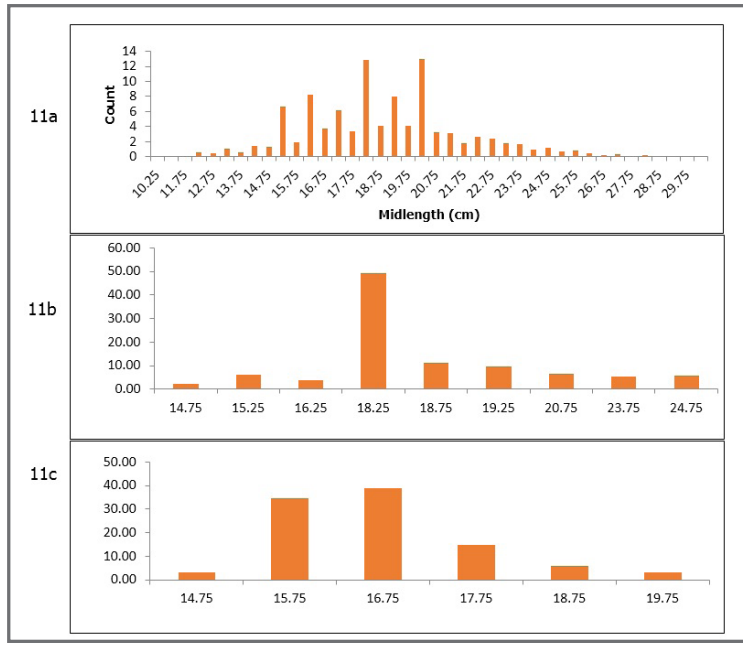

Figure 11. Length frequency distribution showing the length at first maturity of Selar crumenophthalmus caught in Sarangani Bay, 2008-2012.

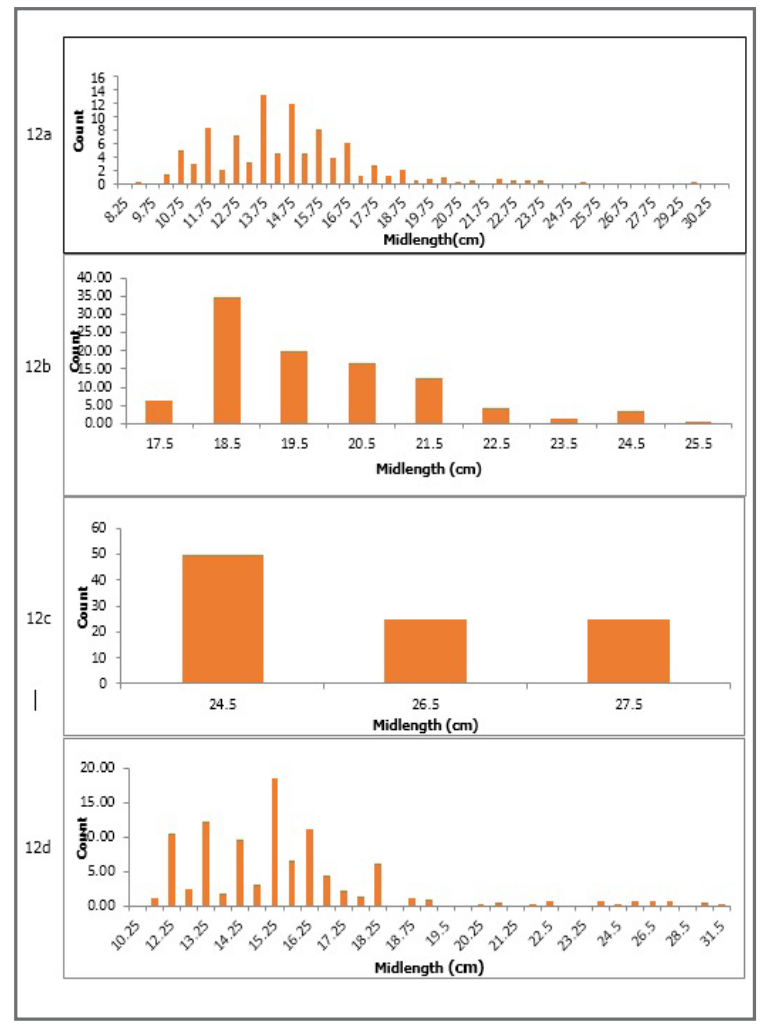

Figure 12. Length frequency distributions showing the length at first maturity of Rastrelliger kanagurta caught in Sarangani Bay, 2008-2012. 
Table 4. Annual values of growth parameters obtained for Mene maculata, Selar crumenophthalmus and Rastrelliger kanagurta caught in Sarangani Bay, 2008-2012.

\begin{tabular}{|c|c|c|c|c|c|c|c|c|}
\hline \multirow{2}{*}{ Year } & \multicolumn{2}{|c|}{ Lmax } & \multirow[t]{2}{*}{$\mathrm{L}_{\infty}$} & \multirow{2}{*}{$\begin{array}{c}\mathrm{L}_{\infty} \\
\text { (Literature) }\end{array}$} & \multirow{2}{*}{$\begin{array}{c}\mathrm{K} \\
\left(\text { year }^{-1}\right)\end{array}$} & \multirow{2}{*}{$\begin{array}{c}\mathrm{K} \\
\text { (Literature) }\end{array}$} & \multirow[t]{2}{*}{$\varnothing^{\prime}$} & \multirow{2}{*}{$\begin{array}{c}\varnothing^{\prime} \\
\text { (Literature) }\end{array}$} \\
\hline & Observed & Predicted & & & & & & \\
\hline \multicolumn{9}{|l|}{ M. maculata } \\
\hline 2008 & - & - & - & & - & & - & \\
\hline 2009 & 21.25 & 21.28 & 22.62 & \multirow{4}{*}{22.5} & 1.2 & \multirow{4}{*}{1.2} & 2.78 & \multirow{4}{*}{2.79} \\
\hline 2010 & 21.38 & 21.40 & 22.72 & & 1.0 & & 2.60 & \\
\hline 2011 & 20.88 & 20.82 & 22.72 & & 1.0 & & 2.71 & \\
\hline 2012 & 19.88 & 20.09 & 20.12 & & 1.2 & & 2.68 & \\
\hline \multicolumn{9}{|l|}{ S.crumenophthalmus } \\
\hline 2008 & 28.13 & 29.56 & 28.5 & \multirow{5}{*}{$\begin{array}{c}23.3 \\
\text { to } \\
36.5\end{array}$} & 1.6 & \multirow{5}{*}{$\begin{array}{c}0.86 \\
\text { to } \\
2.07\end{array}$} & 3.11 & \multirow{5}{*}{$\begin{array}{c}2.81 \\
\text { to } \\
3.24\end{array}$} \\
\hline 2009 & 27.38 & 29.76 & 31.0 & & 2.0 & & 3.21 & \\
\hline 2010 & 20.25 & 21.09 & 22.0 & & 1.9 & & 2.96 & \\
\hline 2011 & 26.25 & 27.67 & 28.5 & & 2.0 & & 3.21 & \\
\hline 2012 & 24.88 & 24.93 & 25.42 & & 1.4 & & 2.96 & \\
\hline \multicolumn{9}{|l|}{ R. kanagurta } \\
\hline 2008 & - & - & - & - & - & & & \\
\hline 2009 & 32.38 & 32.59 & 32.52 & \multirow{4}{*}{$\begin{array}{c}20.5 \\
\text { to } \\
39.0\end{array}$} & 1.2 & \multirow{4}{*}{$\begin{array}{c}0.7 \\
\text { to } \\
2.10\end{array}$} & 3.06 & \multirow{4}{*}{$\begin{array}{c}2.84 \\
\text { to } \\
3.31\end{array}$} \\
\hline 2010 & 29.75 & 31.89 & 29.44 & & 1.2 & & 3.01 & \\
\hline 2011 & 30.63 & 30.72 & 29.66 & & 1.1 & & 2.99 & \\
\hline 2012 & 27.25 & 26.80 & 27.13 & & 1.2 & & 2.94 & \\
\hline
\end{tabular}

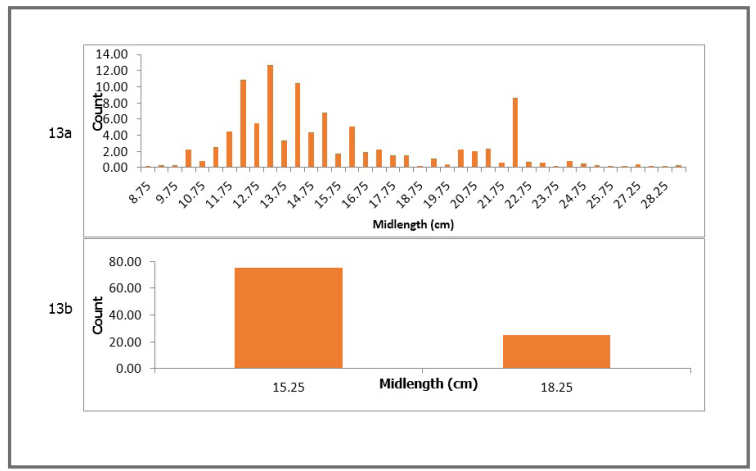

Figure 13. Length frequency distribution showing the length at first maturity of Decapterus macrosoma caught in Sarangani Bay, 2008-2012.

\section{Growth Parameters}

Table 4 shows the growth parameter values obtained for M. maculata, S. crumenophthalmus, and $R$. kanagurta for 2008-2012. Data sets with a minimum of ten months length frequency are the basis of selection of species to be analyzed in FiSAT. For M. maculata, there is only slight variation in $\mathrm{L}_{\infty}$ and so with its growth coefficient (k) values. For S. crumenophthalmus, there is a variation in $\mathrm{L}_{\infty}$ ranging from 22-31 for five years and 2009 is observed the highest at $31 \mathrm{~cm}$ while growth coefficient (k) values also vary but is highest in 2009 . For R. kanagurta, there is also a slight variation in the results obtained for $\mathrm{L}_{\infty}$ and growth coefficients $(\mathrm{k})$ values are the same except for 2012.

To test the validity of the computed growth parameters, estimates of phi prime $\left(\varnothing=\log _{10}+2 \log _{10}\right.$ $L_{\infty}$ ) is compared to the previous study (Table 6) and results obtained for analyzed species are within the range indicated in the literature.

124

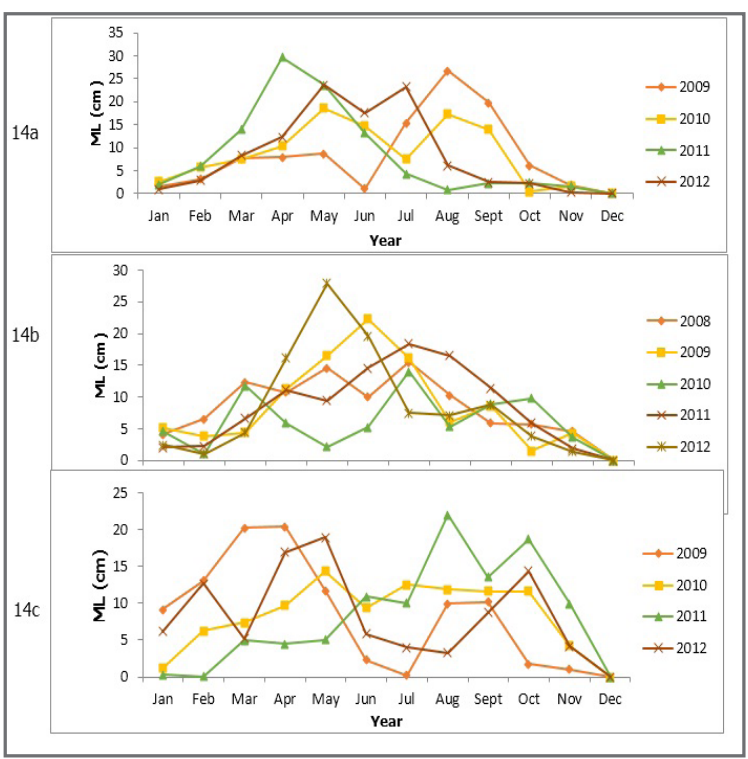

Figure 14. Monthly recruitment pattern observed for Mene maculata (14a), Selar crumenophthalmus (14b), and Rastrelliger kanagurta (14c) caught in Sarangani Bay, 2008-2012.

\section{Recruitment Pattern}

Figure 14 shows the cohortanalysisfor threemajor species; M. maculata (2009-2012), S. crumenophthalmus (2008-2012), and Rastrelliger kanagurta (2009-2012). Recruitment of S. crumenophthalmus varies in every year. The percentage of recruitment is highest in the month of August 2009, May 2010, April 2011, and July 2012. For M. maculata, the highest recruitment is observed in April 2009, May 2010, August 2011, and May 2012. While $R$. kanagurta, recruitment is observed in the last month of the first quarter up to the second quarter from 2008-2012 and it peaks in May 2012. 
The Philippine Journal of Fisheries 25 (1): 118-127

Table 5. Annual values of mortality parameters obtained for Mene maculata, Selar crumenophthalmus, and Rastrelliger

kanagurta caught in Sarangani Bay, 2008-2012.

\begin{tabular}{|r|c|c|c|c|}
\hline \multicolumn{1}{|c|}{ Year } & $\begin{array}{c}\text { Z } \\
\left(\text { year }^{-1}\right)\end{array}$ & $\begin{array}{c}\mathrm{M} \\
\left(\text { year }^{-1}\right)\end{array}$ & $\begin{array}{c}\mathrm{F} \\
\left(\text { year }^{-1}\right)\end{array}$ & $\begin{array}{c}\mathrm{E} \\
(\mathrm{F} / \mathrm{Z})\end{array}$ \\
\hline M. maculata & & & & \\
\hline 2008 & - & - & -- & - \\
\hline 2009 & 5.20 & 2.18 & 3.02 & 0.58 \\
\hline 2010 & 1.16 & 2.0 & 1.78 & 0.47 \\
\hline 2011 & 5.83 & 1.93 & 3.90 & 0.67 \\
\hline 2012 & 7.76 & 2.25 & 5.51 & 0.62 \\
\hline S.crumenophthalmus & & & & \\
\hline 2008 & 6.02 & 2.46 & 3.56 & 0.59 \\
\hline 2009 & 5.81 & 2.79 & 3.03 & 0.52 \\
\hline 2010 & 6.09 & 2.96 & 3.13 & 0.51 \\
\hline 2011 & 8.17 & 2.85 & 5.32 & 0.65 \\
\hline 2012 & 5.05 & 2.33 & 2.72 & 0.54 \\
\hline & & & & \\
\hline 2008 & - & - & - & - \\
\hline 2009 & 3.33 & 1.86 & 1.47 & 0.44 \\
\hline 2010 & 5.98 & 1.87 & 4.11 & 0.69 \\
\hline 2011 & 4.54 & 1.90 & 2.64 & 0.58 \\
\hline 2012 & 3.80 & 2.07 & 1.73 & 0.49 \\
\hline & & & & \\
\hline kanagurta & & & \\
\hline & & & & \\
\hline
\end{tabular}

\section{Mortalities and exploitation}

Table 5 shows the annual values of total (Z), natural $(\mathrm{M})$, and fishing $(\mathrm{F})$ mortalities and exploitation rate (E) obtained for the three major pelagic species caught in Sarangani Bay, 2008-2012. For M. maculata, F-values obtained exceeded the M-values except for year 2010 and E-values ranges from $0.47^{\text {year- } 1}$ to $0.67^{\text {year- }-1}$. Observations on the values obtained for Selar crumenophthalmus, F-values exceeded M-values in all years. E-values obtained ranges from $0.51^{\text {year-1 }}$ to $0.65^{\text {year-1 }}$. For R. kanagurta, F-values for 2010 and 2011 are higher than M-values and E-values ranges from $0.44^{\text {year-1 }}$ to $0.69^{\text {year- }-1}$.

Figure 15 shows the comparative values of E-values obtained for mortalities to E10 analyzed for the three major pelagic fish species for the year 2008-2012. As the figure suggests, the average E-value of $0.56^{\text {year- } 1}$ is higher than the average E10 value of 0.44 year-1

\section{Length at First Captivity, Maturity, and High Captivity}

Table 6 shows the average lengths $(\mathrm{cm})$ of major three species analyzed at its first maturity $(\mathrm{Lm})$, first captivity (L25), and length having the highest fishing mortality rate. The values of Lm and L25, M. maculata is at a very critical stage since L25 value is very much closer or closely equal to $\mathrm{Lm}$. This implies recruitment overfishing since high exploitation is observed wherein this species is caught at length of its first maturity. But for R. kanagurta and S. crumenophthalmus, values of L25 is half the values of $\mathrm{Lm}$ and this indicates overexploitation and the stocks are overfished. These species are caught before they are able to grow and mature. This implies growth and recruitment overfishing.
Table 6. Average length $(\mathrm{cm})$ of the three pelagic species at its first maturity (Lm), first captivity (L25), and length having the highest fishing mortality rate.

\begin{tabular}{|l|c|c|c|}
\hline \multicolumn{1}{|c|}{ Scientific Name } & Lm & L25 & $\begin{array}{c}\text { With high } \\
\text { Fishing } \\
\text { Mortality } \\
\text { (F) }\end{array}$ \\
\hline 1. Mene maculata & 14 & 14.7 & 16.4 \\
\hline 2. Rastrelliger kanagurta & 23 & 11.36 & 28.6 \\
\hline 3. Selar crumenophthalmus & 21.5 & 12 & 21.9 \\
\hline
\end{tabular}

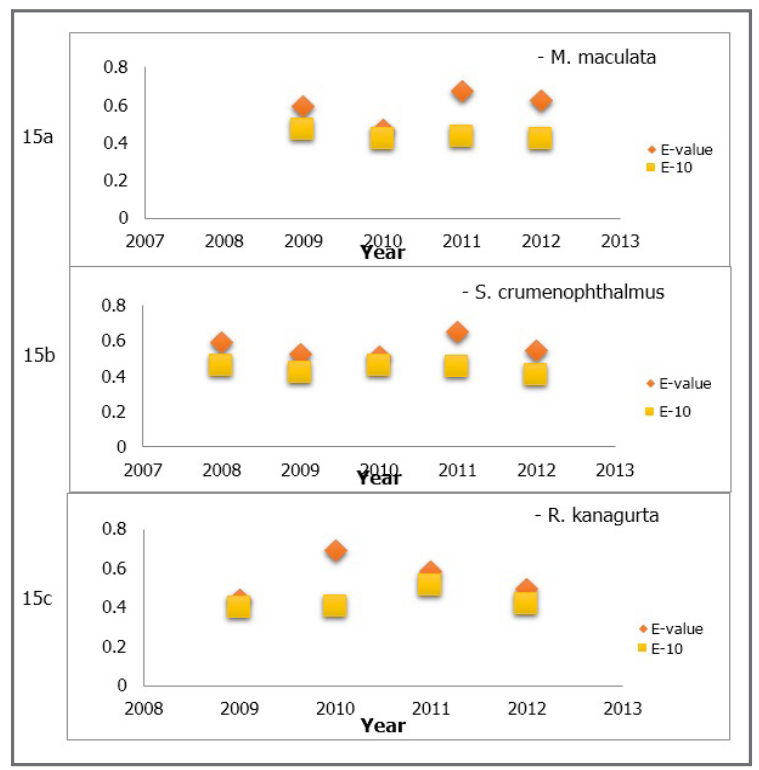

Figure15. Comparative values of exploitation to E10 of relative yield per recruit observed for M. maculata, S. crumenophthalmus, and R. kanagurta caught in Sarangani Bay, 2008-2012.

\section{D I S C US S I O N}

Historically, Sarangani Bay has rich coastal marine resources and the Bay is being increasingly impacted by development. According to some fishermen, illegal fishing is still practiced by some that contributed much to the decline of the fish catch.

Although Sarangani Bay was proclaimed as a protected seascape, thereby making it a part of the National Integrated Protected Areas System (NIPAS) of DENR. Currently, DENR has general administration of Sarangani Bay, but the coastal users believe that DENR is not focusing enough attention on Sarangani Bay as protected seascape (De Jesus, et al. 2001).

Every province, municipalities, and cities, even barangays, in most parts of the country has a very good enforcement law and ordinances but the enforcement and implementation of the law are very weak. And according to De Jesus et al. in 2001, Sarangani Province and General Santos City are no exception.

Sarangani Bay Fish Stock Assessment Project (SBFSAP) in 1996 compared Sarangani Bay as richer and 
Table 7. Fish abundance and diversity of Sarangani Bay (pelagic and demersal) compared with other bays in South Central Mindanao, Philippines.

\begin{tabular}{|c|c|c|c|c|}
\hline \multirow{2}{*}{ Name of Bay } & \multicolumn{3}{|c|}{ Count } & \multirow{2}{*}{ References } \\
\hline & Family & Genus & Species & \\
\hline Sarangani Bay (Southern Mindanao) & 47 & 99 & 249 & This Study (2008-2012) \\
\hline Sarangani Bay (Southern Mindanao) & 83 & - & 401 & $\begin{array}{l}\text { Sarangani Bay Fish Stock } \\
\text { Assessment Project (SBFSAP } \\
1996 \text { ) }\end{array}$ \\
\hline Bais Bay (SE Negros) & 52 & - & 159 & $\begin{array}{l}\text { Environment-Resource } \\
\text { Management Project (ERM- } \\
\text { P)-Siliman University Marine } \\
\text { Laboratory (SUML), } 1993 \\
\end{array}$ \\
\hline Panguil Bay (N. Mindanao) & 73 & - & $\begin{array}{c}145 \text { and } \\
201\end{array}$ & $\begin{array}{l}\text { Panguil Bay Carigara Bay } \\
\text { Resource Ecological Assess- } \\
\text { ment (REA) Minadanao State } \\
\text { (MSU), Naawan, undated, } \\
\text { Sanguila, } 1984 \\
\end{array}$ \\
\hline Sogod Bay & 74 & - & 347 & $\begin{array}{l}\text { Sogod Bay Resource Ecologi- } \\
\text { cal Assessment (REA)-Siliman } \\
\text { University Marine Laboratory } \\
\text { (SUML), } 1994\end{array}$ \\
\hline
\end{tabular}

Table 8. Volume of fish catch (MT) from commercial and municipal sector in Sarangani Bay.

\begin{tabular}{|c|c|c|c|}
\hline Year & Municipal & Commercial & Total \\
\hline 1995 & $2,087.7$ & 75.6 & $2,163.3$ \\
1996 & $2,119.9$ & 71.8 & $2,191.7$ \\
1997 & $2,162.8$ & 68.2 & $2,231.0$ \\
1998 & $2,328.0$ & 64.8 & $2,392.8$ \\
1999 & $2,450.4$ & 61.6 & $2,512.0$ \\
2000 & $2,737.5$ & 88.6 & $2,826.1$ \\
2001 & $2,432.8$ & 55.6 & $2,488.4$ \\
\hline TOTAL & $\mathbf{1 6 , 3 1 9 . 2}$ & $\mathbf{4 8 6 . 2}$ & $\mathbf{1 6 , 8 0 5 . 3}$ \\
\hline
\end{tabular}

Source: SBFSAP (1996)

diverse than the other bays facing similar fishing pressure in the South Central Philippines. Top species recorded for the study conducted by Sarangani Bay Fish Stock Assessment Project in 1996 were also included in the major species monitored in terms of weight. This study recorded 47 families and 249 species only, which has a decrease in species abundance compared to the previous study of SBFSAP in 1996, wherein the author monitored 83 families and 401 species (Table 7). According to the historical background of the Coastal Environmental Profile of the Sarangani Bay, one of the issues related to integrated coastal management, is the resource exploitation issue. A major issue concerning resource exploitation is the encroachment of commercial fishers in municipal waters (De Jesus, at. al. 2001) and based on the interview with the local residents, destructive fishing practices still exist.

Historical data on the volume of fish catch was also presented in the report of Sarangani Fish Stock Assessment Project (SBFSAP, 1996) as can be seen in Table 8. The author took these data from BFAR XI under the Ginintuang Masaganang Ani (GMA) where the LGU fishery coordinators submitted fisheries production data by municipality as their commitment to BFAR. The year 2000 recorded the highest production for both commercial and municipal sector while 2001 had the lowest production data. In addition, the municipal sector dictated the production where this study focused on pelagic species caught in municipal water.

In this study, there were 12 families of pelagic species (Scombridae, Carangidae, Clupeidae, Coryphaenidae, Engraulidae, Exocoetidae, Menidae, Sphraenidae, Megalopidae, Trichiuridae, Gempylidae and Belonidae) with 59 recorded species of pelagic fishes were caught by different gears.

In the previous study conducted by Edgar A. De Jesus and colleagues for the whole fishery resources, among the fish species observed, the most represented families were Pomacentridae, Labridae, Chaetodontidae, and Acanthuridae. However, in the results of Sarangani Bay Fish Stock Assessment Project in 1996 Cypselurus sp., Sardinella lemuru, Thunnus albacares, Decapterus macrosoma, and Stolephorus punctifer (Encrasicholina punctifer) were found to be the top five major species and happened to be included in the top ten major species of 
this paper (NSAP data 2008-2012).

The Sarangani Bay supports a multi-gear and multi-species fishery. Table 8 shows the different types of gears used in catching small pelagic species in Sarangani Bay for 2008-2012. These gears are categorized into its generic names with corresponding common and local names used in the locality. The gears are categorized into six types: impounding net, pull or drag, entangling, lines, barriers, and traps. Twelve gears were given local names for easy understanding of the local readers.

\section{S UMMA R Y}

The Sarangani Bay is still not in a healthy state proven by the decreasing catch of small pelagic from $92 \%$ in 2008 to $86 \%$ in 2012 (NSAP, 2008-2012) and decreased in species diversity from 83 families and 401 species (SBSAP, 1996) to 47 families and 249 species (NSAP, 2008-2012).

There is also an implications of growth and recruitment overfishing of the three major species analyzed (M. maculata, R. kanagurta, and S. crumenophthalmus) based on the values of Lm and L25 derived from FiSAT 2. Supported by the length frequency data is the Lm where high percentage catches of immature sizes of major species shown (Figure 10,11, 12 and 13) were caught before they are allowed to grow and another indicator is the comparison of the exploitation rates obtained from mortalities with the optimum value $\mathrm{E}=0.5$ and $\mathrm{E} 10$.

Data collection is done on the left side of the bay only and expansion on right side will totally answer the current status of the bay

\section{A C K N O W L E D G M ENT S}

The authors would like to thank the following:

The personnel and staff of Bureau of Fisheries and Aquatic Resources (BFAR)-Central Office, to Atty. Asis G. Perez, Mr. Noel C. Barut and Dr. Mudjeekeewis D. Santos of National Fisheries Research Development Institute, OIC-RD Ambutong K, Pautong, BFAR-Regional Office No. 12, for the administrative and financial support. Mr. Nygiel B. Armada, Dr. Geronimo T. Silvestre, and Dr. Ethel Lllana for reviewing and editing the results of this study.

Ms. Sheryl Mesa of Region 6, Fe LavapieGonzales and Ms. Eunice Bognot of NFRDI in the species identifications, all data analysts, data enumerators, all fisherfolk, fishery technicians, local government officials of landing sites covered in this study for all the support and cooperation. possible.

Without your supports, this paper would not be

\section{R E F E R E N C E S}

Aprieto VL. 1992. A Survey of the marine Fisheries of Sarangani, South Cotabato. Fisheries Research Journal of the Philippines. Volume 17: 95.
De Jesus EA, Diamante-Fabunan DAD, Nanola C, White AJ, Cabangon HJ. 2001. Coastal Environment Profile of the Sarangani Bay Area, Mindanao, Philippines. Coastal Resource Management Project, Cebu City, Philippines, p. 102.

Dalzell P, Ganaden R. 1987. The overfishing of small pelagic fish stocks in the Philippines. Paper presented at the Symposium on the Exploitation and Management of Marine Fishery Resources in Southeast Asia. IPFC, Darwin, Australia, 16-19 Feb 198, p. 249-256.

Dalzell P, Corpuz PV. The present status of small pelagic fisheries in the Philippines, p.25-51. In C.R. Pagdilao and C.D Garcia (eds) Philippine tuna and small pelagic fisheries:status and prospects for development Philippine Council for Aquatic and Marine Research and Development, Los Banos, Laguna.

Environment-Resource Management Project (ERMP)Siliman University Marine Laboratory (SUML). 1993

Gayanilo FC, Sparre P, Pauly D. The FAO-ICLARM Stock Assessment Tools (FiSAT) User's Guide. FAO Fishing Computerized Information Series (Fisheries) No. 8 FAO Rome, 1996, 126.

MSU-SUML (Mindanao State University and Siliman University Marine Laboratory). 1997. Fish stock assessment of Sarangani Bay. General Santos City, Philippines.

SBFSAP. 1996. Sarangani Bay Fish Stock Assessment.

Sogod Bay Resource Ecological Assessment (REA)Siliman UniversityMarine Laboratory (SUML), 1994.

Trinidad AC, Pomeroy RS, Corpuz PV, Aguero M. 1993. Bioeconomics of the Philippine Small Pelagic Fishery. ICLARM Tech. Rep. 38, p. 74.

Yesaki M. 1983. The pelagic fisheies of the Philippines. IPTP/83. WP6, 15 p. Indo-Pacific Tuna Development Management Programme, Colombo, Sri Lanka.

Zaragoza EC, Pagdilao CR, Moreno EP. 2004. Overview of the small pelagic fisheries, $p$ 32-37. In DABFAR(Department of Agriculture-Bureau of Fisheries and Aquatic Resources). In turbulent seas: The status of Philippine marine fisheries. Coastal Resource Management Project, Cebu City, Philippines. 